\title{
PROSES MANAJEMEN EDITORIAL DI GRAMATA PUBLISHING
}

\author{
Meilina Ika Kurniawati, Benget Simamora \\ Program Studi Penerbitan, Jurusan Penerbitan \\ Politeknik Negeri Media Kreatif Jakarta
}

\begin{abstract}
:
This research aims to clarify and expose the causes of the less effective the editorial management process in Gramata Publishing. The descriptive method was used to describe the process of editorial management in Publishing studies based on data Gramata library and observations directly at Gramata Publishing. The results showed an overview the process of publishing a book on Selfpublishing is not raw Gramata. Sometimes in the process of management there is a change for the sake of efficiency.
\end{abstract}

Keywords: management, editorial, publishing

\section{PENDAHULUAN}

H.G. Andriese menjelaskan bahwa penerbit merupakan jenis perusahaan yang sangat khas karena banyaknya pihakpihak yang secara langsung ataupun tidak langsung berinteraksi pada penerbitan. Waktu yang tidak sebentar dan banyaknya jumlah pihak yang terkait, membuktikan bahwa dalam menerbitkan sebuah naskah bukanlah hal yang mudah. Proses yang dilakukan yaitu proses editing oleh editor, proses tata letak oleh layouter, proses pembuatan disain sampul oleh designer cover, proses proof oleh penulis, proses cetak oleh percetakan, dan proses marketing oleh marketer. Walaupun dalam menerbitkan buku bisa saja dilakukan oleh satu orang (self publishing) tetapi hal tersebut akan lebih banyak memakan waktu dan tenaga.
Begitu banyaknya waktu dan tenaga yang diperlukan dalam menerbitkan buku maka diperlukan seorang editor yang bertugas dalam memanajemen editorial. Tugas utamanya adalah agar naskah dapat dikontrol dengan baik. Memanajemen editorial tidak mudah karena diperlukan berbagai kemampuan serta sarana dan prasarana yang mendukung. Kemampuan tersebut antara lain kemampuan berkomunikasi dengan pihak terkait, kemampuan penggunaan program-program yang dibutuhkan, dan kemampuan perencanaan penerbitan buku. Sementara itu, sarana dan prasarana yang mendukung antara lain ketersediaan program manajemen editorial, ketersediaan alat komunikasi, kurangnya sumber daya manusia yang cukup, tempat bekerja yang nyaman, ketersediaan fasilitas beribadah, dan adanya gaya selingkung penerbit. Penerbit buku 
merupakan lembaga atau institusi yang mengolah naskah mentah dari penulis atau pengarang hingga menjadi bahan siap cetak dalam bentuk dummy (prototype buku). Gramata Publishing adalah penerbit buku-buku berkualitas yang sesuai dengan perkembangan ilmu dan pengetahuan, meliputi naskah-naskah bertema pendidikan, referensi, kamus, pengayaan, fiksi anak (petualangan, misteri, dan persahabatan), agama, life-skill, hobi, keterampilan, how to, novel (remaja dan dewasa), dan lain-lain. Bukubuku yang diterbitkan didukung oleh penulis dari berbagai latar belakang profesi. Berdasarkan latar belakang masalah, identifikasi masalah, dan pembatasan masalah penulis hendak menjelaskan dan memaparkan penyebab kurang efektifnya proses manajemen editorial di Gramata Publishing.

Manajemen adalah kegiatan yang sangat kompleks. Menurut KBBI, manajemen merupakan penggunaan sumber daya secara efektif untuk mencapai sasaran. Menurut Encyclopedia of the social science, manajemen adalah suatu proses pelaksanaan tujuan tertentu yang dilaksanakan dan diawasi. Haiman memaparkan bahwa manajemen adalah fugsi untuk mencapai suatu tujuan melalui kegiatan orang lain, mengawasi usaha-usaha yang dilakukan individu untuk mencapai tujuan.

Georgy R. Terry menjelaskan manajemen adalah cara pencapaian tujuan yang telah ditentukan terlebih dahulu dengan melalui kegiatan orang lain. Chaster I Bernard dalam bukunya yang berjudul The Fuction of Executive menyatakan bahwa manajemen yaitu seni dan ilmu. Dari definisi di atas dapat ditarik simpulan bahwa manajemen yaitu koordinasi semua sumber daya melalui proses perencanaan, pengorganisasian, pengarahan, dan pengawasan untuk mencapai tujuan yang telah ditetapkan terlebih dahulu.

Pada umumnya, penerbit mempunyai empat bagian, yaitu bagian editorial, bagian produksi, bagian marketing, dan bagian administrasi. Tulisan ini akan terfokus membahas bagian editorial. Bagian editorial merupakan inti sebuah penerbit. Fungsi utamanya adalah mengembangkan pernaskahan. Di bagian inilah bahan baku penerbitan (naskah) diolah dan dipersiapkan sehingga siap dan layak untuk diterbitkan. Bagian ini bertanggungjawab atas mutu penerbitan. Meskipun pengarang bertanggungjawab penuh atas isi sebuah buku., penerbit yang baik tidak akan menerbitkan naskah yang belum layak terbit. Nama penerbit tidak terlepas dari mutu terbitannya.

Bagian editorial juga bertugas untuk mendapatkan naskah, lalu mempertimbangkannya apakah naskah tersebut dapat diterbitkan. Jika akan diterbitkan, bagian ini mengolah naskah agar siap untuk diproduksi menjadi buku. Bagian editorial banyak berhubungan dengan pengarang selama proses 
penerbitan bukunya. Karena berhubungan langsung dengan pengarang, bagian editorial dapat dikatakan paling mengetahui isi buku dan tahu kepada kelompok pembaca mana buku ini ditujukan.

Sebelum proses penyuntingan dilakukan, seorang editor memeriksa terlebih dahulu kelengkapan naskah, yang meliputi preliminary dan postliminary. Hal ini perlu dilakukan untuk mengetahui apakah semua unsur naskah sudah lengkap atau belum. Preliminary terdiri dari (a) halaman judul naskah, (b) halaman prancis, (c) halaman utama, (d) halaman hak cipta (copyright), (e) halaman persembahan (dedikasi), (f) dafatar isi, (g) daftar tabel, daftar singkatan, daftar lambang, daftar ilustrasi/gambar, (h) prakata, (i) kata pengantar, dan (j) kata pendahuluan. Sementara postliminary terdiri dari (a) daftar kata asing, daftar istilah, (b) daftar pustaka, (c) lampiran, (d) indeks, dan (e) biografi singkat.

Editor dapat membantu pengarang dalam segi bahasa, misalnya dalam pemilihan dan penggunaan kata dan istilah. Dapat juga beberapa data atau keterangan yang perlu diperikasa kebenarannya. Mungkin ada hal yang menyinggung masalah kesopanan, hukum, dan undang-undang negara. Mungkin juga cara penyampaian atau sistematika (urutan) penyajian dapat diperbaiki. Diperlukan petunjukpetunjuk bagi pencetak tentang penampilan buku yang diinginkan sesuai dengan calon pembaca dan cara penggunaan buku tersebut. Pada tahap penyuntingan ini, editor bekerjasama dengan pengarang, dan segala perubahan sebaiknya diketahui dan disetujui oleh pengarang. Selain berhubungan dengan pengarang dalam tahap penyuntingan, editor juga dapat memberi saran-saran dan bantuan pada tahap produksi dan tahap marketing buku.

Manajemen editorial sering disebut dengan istilah "jembatan komunikasi” antara bagian editorial dengan bagian produksi. Bagian editorial berkaitan dengan kualitas isi buku, apakah yang menjadi selukbeluk plot sebuah novel atau keaslian ide naskah. Bagian produksi berfokus pada estetika, misalnya jenis kertas yang terbaik untuk digunakan dalam sebuah buku dan penentuan jenis dan tata letak design. Manajemen editorial berusaha untuk menyatukan dua bagian tersebut agar terciptakan buku-buku yang baik.

Alasan manajemen editorial perlu dilakukan padahal sudah ada bagian produksi dan bagian editorial ialah karena kata kuncinya ada pada kata pertama, yaitu manajemen. Seorang editor yang bekerja untuk memanajemen editorial harus menjaga komunikasi yang baik antara pihak terkait. Selain itu, juga harus mengatur dan mengawasi jadwal buku terbit. Para pihak terkait harus mematuhi deadline yang telah dibuat sebelumnya. Proses menerbitkan buku juga harus terus berjalan dan sering kali editor mengawasi proses tersebut dengan maksimal. 
Misalnya, apakah judul buku dapat menarik perhatian? Apakah masih ada kekurangan dalam hal kelengkapan naskah yang belum terpenuhi? Editor juga tetap mengawasi jumlah halaman buku, terutama jika ada halaman tambahan maka akan perlu ditambahkan ke daftar isi.

Ketika editor dalam memanajemen editorial memakai “topi” produksi, editor akan memprioritaskan penampilan dan tata letak halaman fisik. Halaman widow, halaman orphan, halaman yang bertumpukan - semua istilah ini mengacu pada masalah tampilan tekstual yang muncul ketika naskah ini ditata letak. Meskipun pembaca mungkin tidak menyadari ini, tetapi mata pembaca akan tanpa sadar berhenti jika merasakan pengulangan kata beberapa kali secara berturutturut sepanjang margin kanan, atau jika baris teratas pada halaman buku adalah garis pendek terakhir dari sebuah paragraf diikuti oleh lebih lama potongan teks. Seorang editor harus teliti memeriksa setiap celah dari naskah untuk menemukan gangguan tersebut dan memperbaikinya sebelum diterbitkan.

Ketika editor memakai "topi" editorial, editor bekerja sama dengan editor lain dan penulis untuk menyelesaikan masalah konten yang ditemukan. Jika masih ada konten yang bermasalah, maka akan dikomunikasikan dengan penulis. Aturan penting untuk diingat: Buku adalah "bayinya" penulis. Penulis sering kali menuangkan perasaan dalam bukunya, sehingga sangat penting untuk mengkomunikasikan adanya masalah dalam konten dengan menggunakan bahasa yang baik.

Penerbit buku sebagai institusi yang mengolah naskah mentah dari penulis atau pengarang hingga menjadi bahan siap cetak dalam konteks bisnis yang lebih luas untuk memasuki fase industrial tentunya memerlukan badan hukum. Penerbit berbeda dengan percetakan karena modal utamanya adalah gagasan yang kemudian diolah menjadi buku siap terbit. Adapun percetakan, modal utamanya adalah mesin-mesin yang digunakan untuk menerima order cetak, termasuk buku. Tidak semua penerbit memiliki percetakan dan memang tidak harus pula memiliki percetakan. Percetakan menjadi pendukung untuk percetakan buku secara massal dan cepat.

Gramata Publishing didirikan pada 23 Juli 2009 oleh Nova Rasdiana, mantan direktur Penerbit Rajawali Press. Awalnya, kantor Gramata Publishing berada di Jalan Nusantara Raya No.113 Depok. Namun, sekarang sudah pindah ke alamat Komplek Jatiwarna Indah Jalan Bunga Matahari V Blok E Nomor 1, Pondok Gede - Bekasi. Gramata Publishing sudah tampil dalam penerbitan buku di dunia. Hal ini terbukti dengan keterlibatan Gramata Publishing dalam Frankfurt Book Fair 2012. Walaupun perusahaan ini masuk kategori perusahaan kecil tetapi hingga akhir 
2012, Gramata Publishing telah menerbitkan sekitar 75 judul buku. Dengan motto "Lead Advanced Human Resources”, Gramata Publishing berusaha untuk memberikan sumbangan dalam pengembangan Sumber Daya Manusia yang berkualitas \& mempunyai daya saing tinggi, yang kelak dapat membangun Indonesia. Penulisnya berasal dari beragam profesi, baik dari kalangan akademisi yang bergelar profesor maupun doktor, dari praktisi dan penulis yang peduli terhadap pemberdayaan masyarakat.

Penerbit ada yang disebut penerbit umum, artinya menerbitkan buku populer ataupun ilmiah secara umum. Disamping itu, ada pula penerbit khusus (spesialis) yang menerbitkan buku-buku khusus seperti buku teks (pelajaran), penerbit buku perguruan tinggi, penerbit buku agama/rohani, penerbit buku anak dan remaja, penerbit buku kedokteran, dan penerbitan buku referensi. Setiap penerbit profesional pasti memiliki visi dan misi jangka panjang yang menjadi acuan bagi departemen editorial untuk menghasilkan buku-buku yang berorientasi pada pencapaiannya. Orientasi penerbit bisa dirumuskan sebagai berikut: (1) spesialisasi penerbitan atau fokus penerbitan (positioning); (2) produk buku yang berkualitas; (3) membaca sasaran potensial (segmentation); (4) area marketing dan strategi promosi; (5) pembinaan dan pengembangan SDM.
Berikut ini adalah alur naskah yang biasa terjadi di sebuah penerbit. (a) Naskah dikirim ke penerbit; (b) Naskah dievaluasi, baik dari segi substansi maupun bahasanya oleh editor dan kemudian dipresentasikan kepada bagian marketing; (c) bagian marketing menindaklanjuti dengan observasi pasar. Jika analisis pasar tersebut terlihat baik, bagian marketing menyetujui untuk menerbitkan buku tersebut; (d) naskah kemudian dikirim ke bagian keuangan untuk dilanggarkan biaya produksi dan harga jualnya; (e) bagian produksi melanjutkan proses dengan mempersiapkan naskah sampai siap cetak. Proses persiapan isi dikerjakan oleh tim editor untuk mengedit naskah agar setiap informasi di dalam naskah bisa memenuhi tujuan yang diharapkan; (f) merencana gambar sampul buku, ukuran buku, perizinan gambargambar atau foto yang dipergunakan, penandatanganan kontrak, rencana tanggal terbit, royalti, jumlah terbitan, sampel buku terbit, jumlah sampel untuk promosi, mekanisme promosi, marketing dan lain sebagainya. Pada waktu penyuntingan sedang dilakukan, design juga turut direncanakan; (g) proses penataan letak untuk memposisikan setiap halaman sesuai dengan daya tampungnya; (h) naskah dibaca ulang (proofread) untuk memperbaiki kesalahan yang masih ada. Sebelum dicetak, naskah dikirimkan ke penulis untuk dibaca ulang sekali lagi agar dapat dipastikan bahwa seluruh isi naskah 
benar-benar tidak ada kesalahan; (i) naskah dikirim ke bagian percatakan untuk dicetak, dijilid, dipak, kemudian dikirim ke gudang sehingga siap untuk didistribusikan, baik untuk promosi maupun marketing.

\section{METODE PENELITIAN}

Penulis menggunakan metode penulisan deskriptif dalam menyelesaikan Tugas Akhir ini. Metode deskriptif ini penulis nilai sebagai metode yang paling sesuai, dimana penulis menjabarkan proses manajemen editorial di Gramata Publishing berdasarkan data dan pengamatan penulis di Gramata Publishing. Adapun untuk pengambilan data pendukung, penulis menggunakan dua metode yaitu : (1) Studi pustaka yang dilakukan dengan mencari informasi melalui buku-buku referensi yang relevan dengan penjelasan masalah yang diteliti. Selain dengan media cetak, media online juga bisa membantu dalam pencarian teori. Metode ini dilakukan dengan menjelajahi dunia maya dan mengumpulkan informasi yang tersebar di seluruh dunia dengan memanfaatkan alat pencarian data yang tersambung melalui jaringan internet. (2). Studi Lapangan dengan cara menilik dan mempraktikkan langsung proses manajemen editorial di Gramata Publishing pada saat praktik industri bulan Februari hingga Mei 2013 sebagai editor yang bertugas memanajemenkan editorial.

\section{HASIL DAN PEMBAHASAN}

Manajemen editorial merupakan bagian sentral dalam suatu perusahaan penerbitan, baik penerbitan kecil maupun besar. Kegiatan ini dimulai ketika mencari naskah hingga mempersiapkan naskah menjadi buku dan siap untuk dipasarkan. Ketelitian, kecekatan, dan kepandaian berkomunikasi sangat dibutuhkan bagi seorang editor. Hal ini akan diperlukan agar proses naskah berjalan sesuai dengan sistem yang ada dan ketepatan waktu terbit. Berikut ini adalah proses yang termasuk dalam manajemen editorial.

1. Mendapatkan Naskah.

Tidak sering naskah akan datang begitu saja ke penerbit. Terkadang, penerbit harus mencari naskah dari penulis. Begitu pula yang terjadi di Gramata Publishing. Pekerjaan ini lebih banyak dilakukan oleh direktur. Perguruan tinggi sebagai salah satu pasar Gramata Publishing juga menjadi sumber naskah. Hal ini disebabkan oleh banyaknya naskah yang didapatkan dari para dosen di perguruan tinggi. Daftar beberapa penulis yang berprofesi sebagai dosen dapat dilihat pada Tabel 1.

Gramata Publishing juga membuka kesempatan pada penulispenulis pemula untuk menerbitkan naskahnya. Hal ini terdapat dalam website Gramata Publishing dan grup jejaring sosial yang bernama Rumah Gramata (Gambar 1 dan 2). Pada website tersebut dijelaskan syarat-syarat dalam mengajukan 
naskah.

Tabel 1 Daftar penulis yang merupakan dosen

\begin{tabular}{|c|c|c|}
\hline No. & Judul & Penulis/Pengarang \\
\hline 1. & Wajah Hukum Pidana: Asas dan Perkembangan & Dwidja Priyatno \\
\hline 2. & $\begin{array}{l}\text { Menerobos Positivisme Hukum Kritik Terhadap } \\
\text { Peradilan Asrori }\end{array}$ & Faisal \\
\hline 3. & $\begin{array}{l}\text { Beban Pembuktian dalam Beberapa Praktik } \\
\text { Peradilan }\end{array}$ & Syaiful Bahkri \\
\hline 4. & Metodologi Penelitian Ekonomi Islam & Hendri Tanjung \\
\hline 5. & $\begin{array}{l}\text { Kejahatan Narkotik dan Psikotropika Suatu } \\
\text { Pendekatana Melalui Kebijakan Hukum Pidana }\end{array}$ & Syaiful Bahkri \\
\hline 6. & $\begin{array}{l}\text { Penggunaan Hak Ulayat dalam Investasi } \\
\text { Sumber Daya Alam Pertambangan di Indonesia }\end{array}$ & Ferry Aries Suranta \\
\hline 7. & Hukum Pidana Terorisme & Mahrus Ali \\
\hline
\end{tabular}

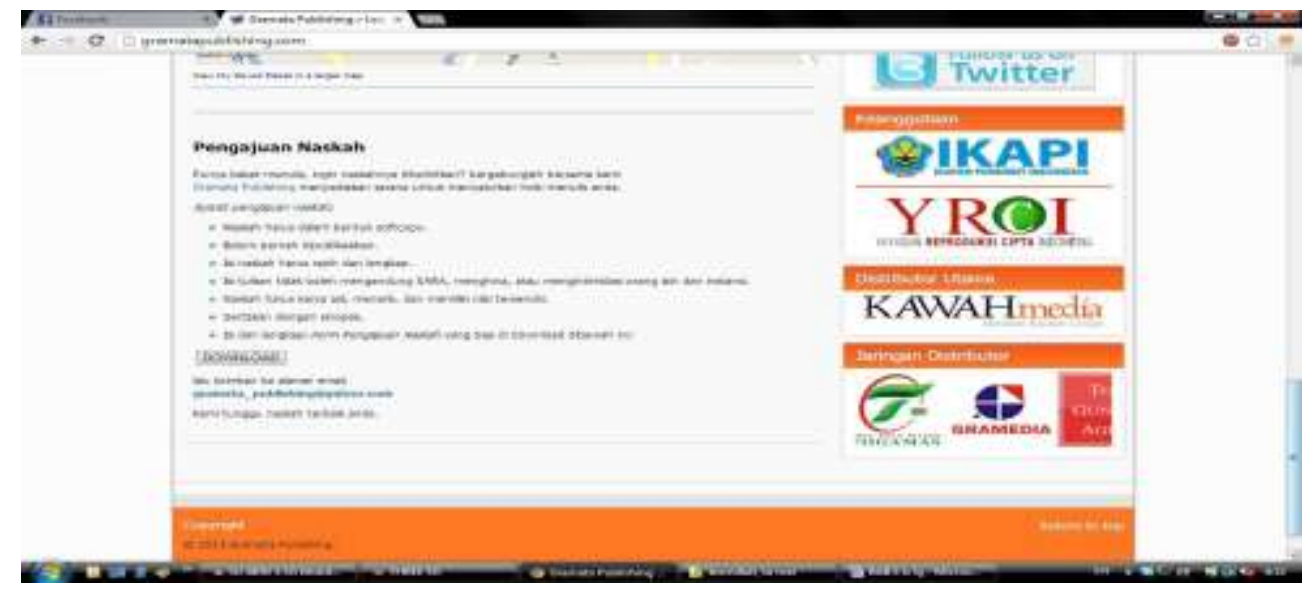

Gambar 1 Website Gramata Publishing

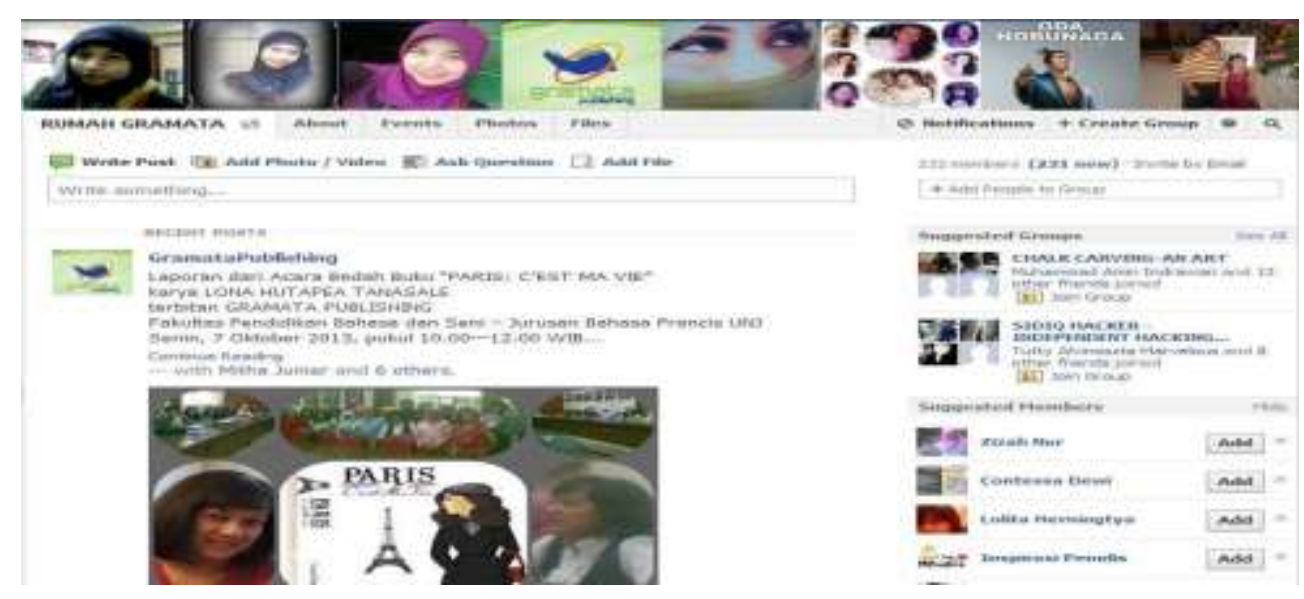

Gambar 2 Group Rumah Gramata

2. Menilai Naskah

Naskah yang masuk harus dinilai kelayakannya. Naskah yang dinilai layak jika memenuhi 
persyaratan yaitu : (a) Naskah yang tidak mengandung SARA dan pornografi; (b) Naskah merupakan karya penulis atau pengarang asli; (c) Terdapat pasar yang akan menjadi target naskah tersebut.

Tabel 2 Contoh naskah masuk

\begin{tabular}{|l|l|c|}
\hline \multicolumn{1}{|c|}{ Judul Sementara Buku } & Status & Keterangan \\
\hline Wajah Hukum Pidana & Layak & - \\
\hline Menerobos Positivisme Hukum & Layak & - \\
\hline Beban Pembuktian & Layak & - \\
\hline $\begin{array}{l}\text { Kejahatan Narkotik dan } \\
\text { Psikotropika }\end{array}$ & Layak & - \\
\hline Hak Ulayat & Layak & - \\
\hline Paris C'est Ma Vie & Layak & - \\
\hline Hukum Pidana Terorisme & Layak & - \\
\hline Jiayi Xiao & Layak & - \\
\hline $\begin{array}{l}\text { Metodologi Penelitian } \\
\text { Ekonomi Islam }\end{array}$ & Layak & - \\
\hline
\end{tabular}

3. Mengidentifikasi dan Memeriksa Kelengkapan Naskah

Setelah naskah dinilai layak atau tidak untuk diterbitkan, maka naskah harus diidentifikasi. Identifikasi naskah mencakup pencatatan jumlah halaman sementara, judul sementara buku, nama penulis (pengarang), dan tanggal rencana buku diterbitkan. Setelah dicatat, naskah perlu diperiksa kelengkapannya. Berikut ini adalah kelengkapan standar Gramata Publishing yaitu ; (a) halaman judul adalah sebuah halaman naskah yang memuat nama penulis/pengarang, judul buku, subjudul buku (jika ada), jilid buku (jika ada), nama penerjemah (jika ada), dan nama penyunting (jika naskah pernah diedit sebelumnya); (b) halaman kata pengantar/prakata. Kata pengantar (foreword) adalah tulisan yang dibuat oleh orang lain, sedangkan prakata adalah tulisan yang dibuat oleh penulis buku (preface); (c) judul bab merupakan cerminan dari pembahasan isi bab yang diwakilinya. Oleh karena itu, judul bab dibuat padat dan ringkas; (d) daftar pustaka adalah halaman tempat mencari daftar buku atau daftar referensi yang digunakan dan dijadikan rujukan penulis untuk menulis bukunya; (e) dengan adanya biografi penulis/pengarang, pembaca akan mengetahui apakah si penulis orang yang berkompeten (memiliki kemampuan) di bidangnya.

4. Memberitahukan Penulis

Penulis diberitahu tentang naskahnya yang akan diterbitkan atau tidak melalui telepon oleh direktur Gramata Publishing. Selain memberitahukan tentang kepastian naskahnya (jika diterima) juga diadakan perbincangan tentang royalti, jumlah oplah, dan lain 
sebagainya. Dilanjutkan dengan pembuatan Surat Perjanjian Penerbitan. Kelengkapan naskah yang kurang juga dapat diminta saat perbincangan tersebut ataupun dapat diminta melalui surat elektronik $(e-$ mail).

5. Menentukan Identitas Naskah

Naskah yang akan diterbitkan menjadi buku haruslah memiliki identitas. Hal ini diperlukan untuk memperindah buku dan menarik pembaca. Editor mempunyai hak untuk memberikan suatu identitas buku. Identitas tersebut antara lain adalah penggunaan jenis huruf, penggunaan ukuran huruf, penggunaan ukuran buku, dan penggunaan jenis kertas buku. Untuk buku teks, jenis huruf yang biasa digunakan jenis huruf berkait, seperti Minion Pro, Adobe Garamond, Bodoni, dan Times New Roman. Sementara itu, untuk ukuran huruf, biasa digunakan 11 poin. Gramata
Publishing memiliki dua ukuran buku, yaitu 14 x $20 \mathrm{~cm}$ dan $17 \times 25$ $\mathrm{cm}$ agar dapat menghemat biaya produksi. Untuk ukuran 14 x $25 \mathrm{~cm}$, jumlah halaman tidak boleh lebih dari 500 halaman, jika lebih dari 500 halaman maka menggunakan ukuran 17 x $25 \mathrm{~cm}$. Jenis kertas yang biasa digunakan adalah bookpaper karena kertasnya ringan.

6. Memberikan Pekerjaan Untuk Editor

Naskah akan diedit oleh seorang editor yang memiliki kemampuan baik editor tersebut adalah seorang karyawan Gramata Publishing maupun tenaga outsourching. Untuk memilih siapakah yang layak untuk mengedit suatu naskah, diadakan rapat. Jika sudah ditentukan orang yang layak, maka editor akan menghubungi editor outsourching tersebut untuk memberikan pekerjaan dan deadline waktu pengerjaannya.

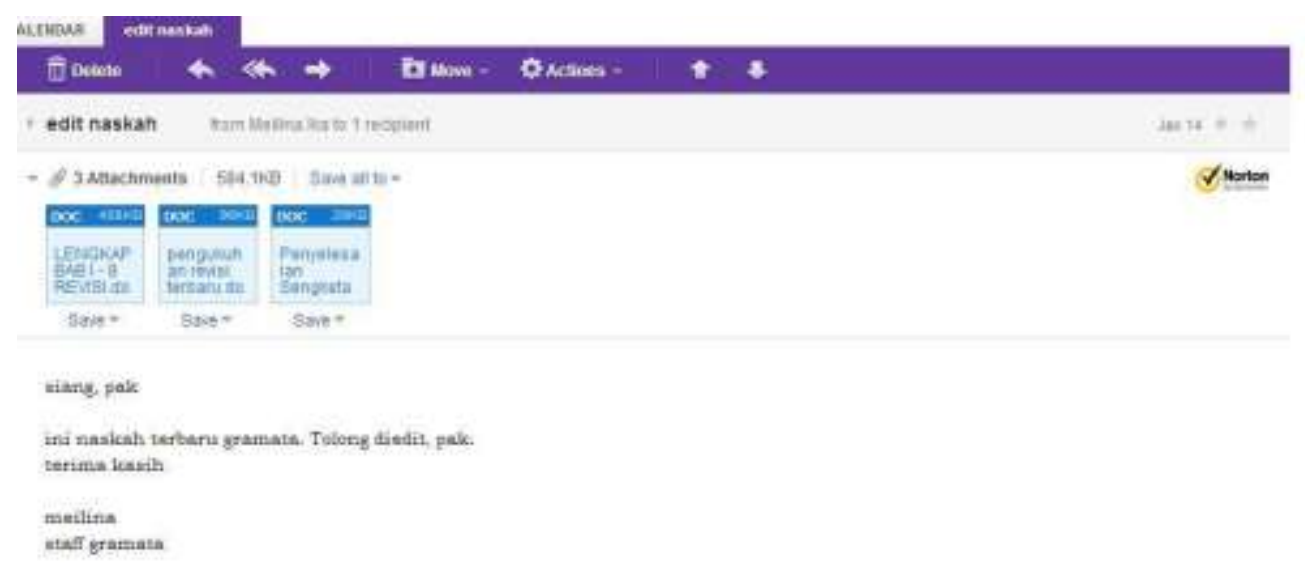

Gambar 3 Memberikan pekerjaan untuk editor

7. Memberikan Pekerjaan Untuk yang akan pertama kali dilihat oleh Designer Cover

Cover buku merupakan hal pembaca. Oleh karena itu, cover buku haruslah menarik. Ada banyak 
designer cover buku yang menjadi tenaga outsourching. Pemberian pekerjaan design cover haruslah sesuai dengan jiwa si designer. Misalnya, untuk buku teks perguruan tinggi, designer A cocok karena dia ahli dalam men-design cover buku teks perguruan tinggi. Dalam pemberian pekerjaan untuk designer cover, penulis menyertakan sinopsis naskah, identitas naskah seperti judul buku, nama penulis/pengarang, dan ukuran buku serta menyertakan konsep cover yang diinginkan

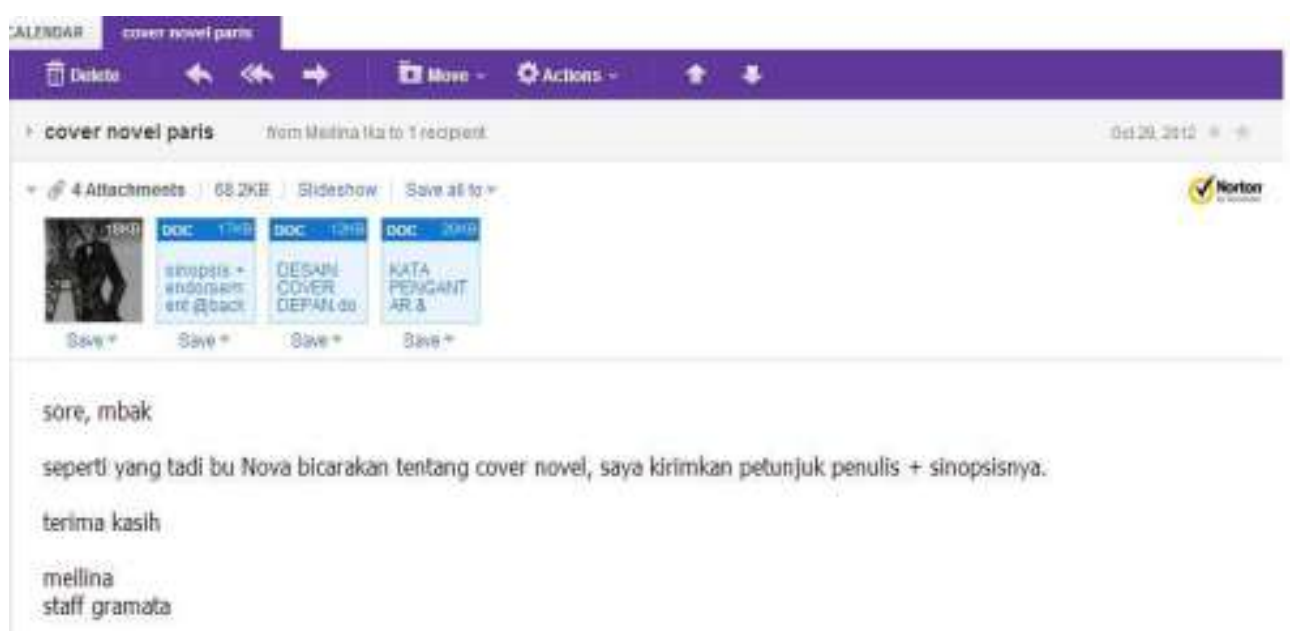

Gambar 4 Memberikan pekerjaan untuk designer cover

8. Memberikan Pekerjaan Untuk

Pekerjaan menata letak naskah masih dikerjakan oleh tenaga outsourching. Oleh karena itu, diperlukan pengawasan yang lebih agar naskah dapat sesuai target waktu pengerjaan. Dalam pemberian pekerjaan untuk layouter, editor menyertakan sinopsis naskah, identitas naskah seperti ukuran buku, jenis huruf yang digunakan, ukuran huruf yang digunakan serta menyertakan konsep yang diinginkan. Biasanya layouter akan mengirimkan contoh hasil pengerjaannya untuk disetujui agar ia dapat bekerja dengan cepat dan tepat.

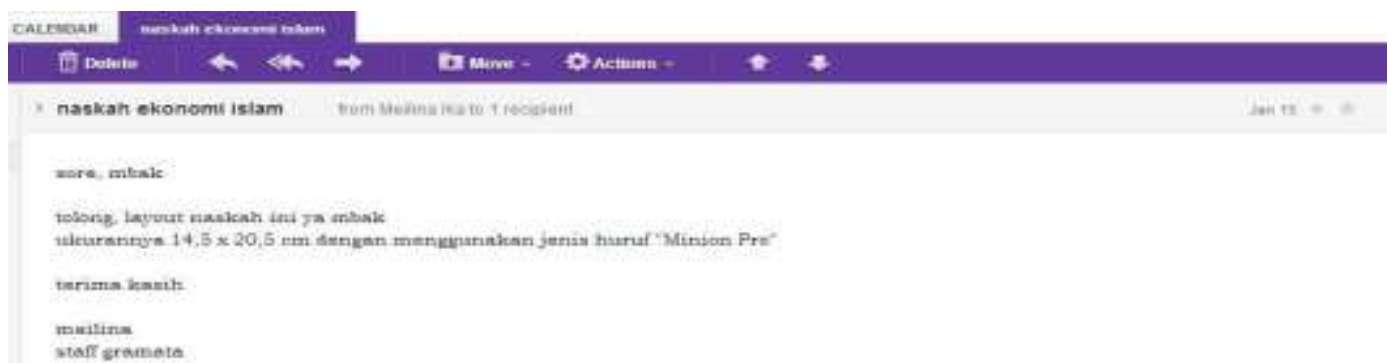

Gambar 5 Memberikan pekerjaan untuk layouter 
9. Melakukan Pengawasan Proses Naskah

Setelah semua pekerjaaan diberikan pada orang yang ahli di bidangnya, maka pekerjaan manajemen editorial belum selesai. Seorang editor harus terus mengawasi proses naskah tersebut. Di bawah ini adalah contoh tabel proses pengawasan naskah.

Tabel 3 Proses pengawasan naskah

\begin{tabular}{|c|c|c|c|c|c|c|c|}
\hline No. & IUDUL & PENULIS & CONER & SEITING & EDITING & ISBN & KETERANGAN \\
\hline \multirow[t]{2}{*}{1} & Menerobos Positivisme & Faisal & bataman & ubah ukuran & sudah ditambah index & done & \\
\hline & Hukum & & on process revisi & meniadi $14,5 \times, 20,5$ & & & \\
\hline \multirow[t]{2}{*}{2} & Beban Pembuktian & Syaiful & done & ria_ubah ukuran & sudah ditambah index & done & sudah dikirim ke penulis \\
\hline & & & & & & & tapi belum ada tanggapan \\
\hline \multirow[t]{2}{*}{3} & Kejahatan Narkotik & Syaiful & done & bataman & done & done & \\
\hline & dan Psikotropika & & sudah dikirim ke ibu & ubah ukuran & & & \\
\hline \multirow[t]{2}{*}{4} & Paris & Lona & tim penulis & done-dikirim ke ibu & farah & done & sudah dikirim ke penulis \\
\hline & & & on process & & tambah kata pengantar & & minta tambahan penganta \\
\hline \multirow[t]{2}{*}{5} & Hukum & Mahrus & done & done & done & done & sudah dikirim penulis \\
\hline & Pidana Terorisme & & & & & & minta revisi coner \\
\hline \multirow[t]{2}{*}{6} & Hukum & Tholabs & none & none & none & none & masih revisi naskah \\
\hline & Keluarga Kontemporer & & & & & & penulis hingga 28 oktober \\
\hline
\end{tabular}

\section{Mengkoreksi Naskah}

Naskah yang sudah diedit dan ditata letak masih harus dikoreksi. Mulai dari kelengkapan naskah hingga perbaikan halaman orphan. Namun, yang biasa dikoreksi hanya penggunaan huruf miring, kelengkapan data pada halaman hak cipta dan penamaan tabel/ilustrasi.

11. Meminta Persetujuan Pruf dari

Direktur dan Penulis

Naskah clean copy dan design cover harus dimintai persetujuan dari direktur dan penulis. Jika sudah disetujui, maka naskah akan diserahkan kepada pihak percetakan untuk dicetak. Biasanya oplah cetakan pertama 2.000 eksemplar. Namun, jumlah ini bergantung pada surat perjanjian penerbitan yang ditandatangani penulis/pengarang dan penerbit.

12. Mendaftarkan ISBN

International Standard Book Number (ISBN) sebenarnya lebih berhubungan pada proses pemesanan sebuah buku pada penerbit. Setiap buku yang diterbitkan pasti mempunyai ISBN yang berbedabeda. Di Indonesia, ISBN dapat didaftarkan pada Perpustakaan Nasional bagian pendaftaran ISBN. Saat mendaftarkan ISBN, harus dilengkapi surat pengantar penerbit, design cover buku, halaman judul buku, halaman kata pengantar, dan halaman daftar isi.

\section{Menghubungi Pihak Percetakan}

Setelah mendapat persetujuan dari direktur dan penulis, sudah mendaftarkan ISBN buku, maka pihak percetakan harus dihubungi 
untuk mengambil data naskah. Siapkan data naskah (cover dan isi naskah clean copy) pada sebuah $\mathrm{CD}$ (compact disk). Sertakan juga sebuah catatan mengenai jumlah halaman dan ukuran buku yang akan dicetak. Biasanya, mencetak buku diperlukan waktu 10 hari terhitung hari kerja.

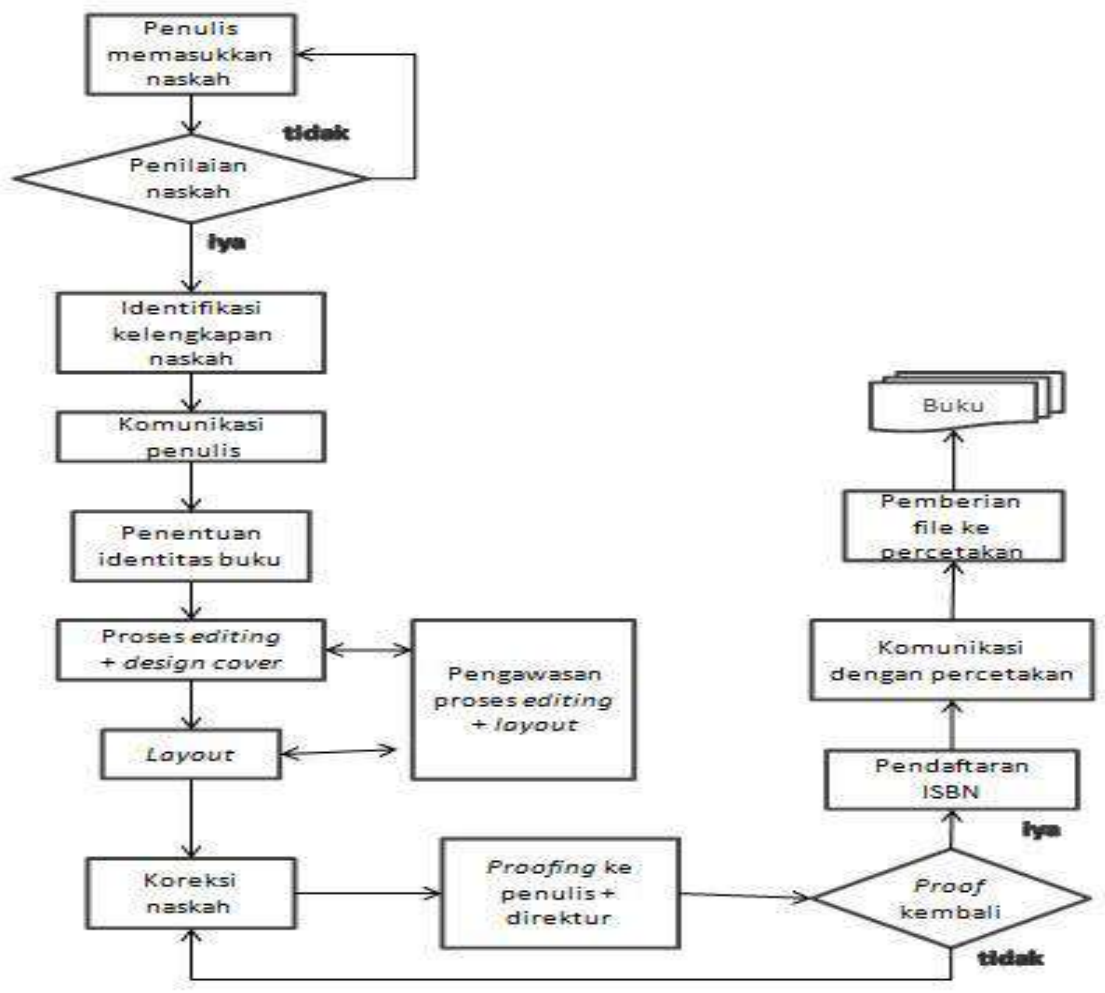

Gambar 6 Proses manajemen editorial di Gramata Publishing.

Dari pembahasan di atas, ada 13 tahapan dalam memanajemen editorial di Gramata Publishing. Tahapan-tahapan tersebut diawasi oleh seorang editor. Dari tahapantahapan muncul berbagai masalah yang menjadi penyebab kurang efektifnya manajemen editorial di Gramata Publishing.

Berikut ini adalah penyebabpenyebabnya: (1) Direktur menangani semua proses penerbitan. Direktur berperan sebagai pemimpin penerbitan dan mengetahui semua proses penerbitan. Namun, terkadang direktur terlalu banyak mengambil alih. Contoh kasusnya dalam mencari naskah. Direktur mencari naskah yang cocok dari perguruan tinggi dan melakukan pembicaraan tentang naskah yang didapat tersebut. Padahal seharusnya, tugas ini adalah tugas dari editor akuisisi. Membangun hubungan antarpenerbit merupakan salah satu tugas direktur. Ini dibuktikan dengan keikutsertaan direktur sebagai pengurus IKAPI (Ikatan Penerbit Indonesia). Hal ini tentu positif bagi perkembangan penerbit. Namun, terkadang direktur 
menjadi sangat sibuk sehingga ia tidak bisa mengurusi proses naskah. (2) Editor mengurusi ISBN. Editor yang dimaksud adalah editor yang bertugas memanajemen editorial. Memproses ISBN bukan merupakan hal yang sulit. Namun, hal ini akan sangat sulit ketika banyak naskah masuk dan harus segera dinilai sedangkan banyak naskah yang harus segera diterbitkan. (3) Kekurangan SDM sangat berpengaruh pada kinerja editor. Editor terkadang harus bekerja di luar job desk-nya. Hal ini tentu memakan banyak waktu, karena editor harus belajar terlebih dahulu padahal ada naskah yang harus segera dikoreksi. (4) Tidak tersedianya program manajemen editorial. Gramata Publishing belum memiliki program komputer memanajemen editorial. Program ini harusnya ada di setiap komputer yang ada di Gramata Publishing dan saling berhubungan. Sehingga setiap karyawan pun dapat mengaksesnya dan menambahkan informasi terbaru ke dalam program tersebut. Selama ini, manajemen editorial dilakukan dengan menggunakan program Microsoft Excel dan buku catatan. Hal ini agak menyulitkan karena buku catatan tersebut tidak boleh tertinggal ataupun hilang. Data dalam program Microsoft Excel pun rawan terserang virus.

\section{PENUTUP}

Proses menerbitkan buku Gramata Publishing tidaklah baku sesuai pembahasan. Terkadang, dalam proses tersebut ada yang berubah demi efisiensi. Misalnya, untuk mengurus ISBN. Pengurusan ISBN dapat dilakukan saat menunggu pruf penulis. Kekurangan SDM dan tidak adanya program komputer yang efektif untuk memanajemen editorial adalah beberapa penyebab kurang efisiennya menajemen editorial di Gramata Publishing. Proses manajemen hanya dilakukan oleh satu orang. Hal ini kurang efektif jika dalam proses mengoreksi naskah, ternyata ada naskah yang baru masuk.

\section{DAFTAR RUJUKAN}

Andriese, H.G. 1993. Pengelolaan Penerbitan Buku 1. Jakarta: Pusat Grafika Indonesia.

Leo, Sutanto. 2010. Kiat Jitu Menulis \& Menerbitkan Buku. Jakarta: Penerbit Erlangga.

Mukhyi, Mohammad Abdul. 1995. Pengantar Manajemen Umum. Jakarta: Gunadarma.

Robbins, Stephen P. 2004. Manajemen. Edisi Ke-7. Jakarta: Indeks.

Smith (Jr.), Datus C. 1975. Penuntun Penerbitan Buku. Jakarta: Pusat Grafika Indonesia.

Tim Penyusun. 2005. KBBI. Edisi Ke-III. Jakarta: Balai Pustaka.

Trim, Bambang. 2009. Taktis Menyunting Buku. Bandung: Maximalis.

Wb, Iyan. 2007. Anatomi Buku. Bandung: Kolbu.

Hafiz, Abdel. 2012. "Organisasi Lini dan Fungsional" dalam http://abdelhafizka09.blogspot. 
Jurnal Publipreneur, Vol. 2, Nomor 3, Juni 2014, ISSN: 2338-5049

com/2012/11/organisasi-lini-

Day in the Life of Managing

dan-fungsional.html. diakses

Editorial"

dalam

pada 10 September 2013.

http://youngtopublishing.com/2

Powers, Tara. Tanpa Tahun.

011/04/managing-ed/. diakses

"Spotlights and Sound Bites: A

pada 20 September 2013. 